\title{
The China-Pakistan Economic Corridor
}

\author{
Tapping Potential to Achieve the \\ 2030 Agenda in Pakistan
}

Murad Ali

\begin{abstract}
The year 2015 marked the deadline for finishing the Millennium Development Goals (MDGs) as the United Nations (UN) member states launched the 2030 Agenda for Sustainable Development with its Sustainable Development Goals (SDGs). The UN 2030 Agenda encompassing 17 goals and 169 targets aims at eradicating global poverty, combating inequalities and utilizing natural resources in a sustainable manner so that "no one is left behind." All stakeholders have committed to proceeding with the incomplete agenda of the MDGs and achieve the SDGs by 2030. Also in 2015, China initiated the China-Pakistan Economic Corridor (CPEC), a collection of projects to develop energy, industry and communication infrastructure costing US $\$ 46$ billion as a key part of the "Belt and Road Initiative (BRI)." This paper examines different components of the CPEC and explores the extensive convergence between the main goals envisioned under the CPEC and the universally accepted SDGs. It posits
\end{abstract}

Murad Ali is a Postdoctoral Research Fellow at the German Development Institute (DIE) and Assistant Professor at the University of Malakand in Pakistan. His mailing address is: Deutsches Institut für Entwicklungspolitik (DIE), Tulpenfeld 6, 53113 Bonn, Germany. He can also be reached at muradali.uom@gmail.com.

(c) 2018 World Century Publishing Corporation and Shanghai Institutes for International Studies China Quarterly of International Strategic Studies, Vol. 4, No. 2, 301-325

DOI: $10.1142 / S 2377740018500094$

This is an Open Access article, copyright owned by the SIIS and WCPC. The article is distributed under the Creative Commons Attribution 4.0 (CC BY-NC) Licence. Further distribution of this work is permitted, provided the original work is properly cited and for non-commercial purposes. 
that if successfully implemented, the CPEC will contribute to achievement of various SDGs in Pakistan. While it is expected that the CPEC will enable the country to move forward on a number of SDGs, three goals are particularly relevant to the construction of the CPEC. The paper argues that there is immense potential for convergence, commonality, and division of labor for a host of bilateral and multilateral actors to enhance the Global Partnership for Sustainable Development (SDG17), resolve political differences, participate in the CPEC, and contribute to the implementation of the UN 2030 Agenda even beyond Pakistan in the broader South Asian region.

Keywords: China-Pakistan Economic Corridor (CPEC); "Belt and Road Initiative (BRI);" UN 2030 Agenda for Sustainable Development; Sustainable Development Goals (SDGs).

In September 2015, the United Nations (UN) member states universally adopted the 2030 Agenda for Sustainable Development (hereafter "UN 2030 Agenda") at the 70th UN General Assembly (UNGA). All signatories, both developed and developing countries, have agreed to implement the UN 2030 Agenda and try to achieve the 17 ambitious and multifaceted Sustainable Development Goals (SDGs). In February 2016, Pakistan embraced the UN 2030 Agenda through a unanimous parliamentary resolution, for the country's long-term development plan, Vision 2025, are closely aligned with the Agenda and its SDGs.

How can Pakistan make real progress toward achieving the UN 2030 Agenda and various SDGs? Doubtlessly, this will require unprecedented financial resources alongside favorable policies and institutional environment. Focusing on the potential impact of huge financial inflows to various sectors of the economy, this paper attempts to examine how the ChinaPakistan Economic Corridor (CPEC) contributes to the operation and implementation of the UN 2030 Agenda in Pakistan and explore how the country can make progress toward a number of SDGs by effectively utilizing and harmonizing vast opportunities offered by the CPEC. Like numerous other developing countries, generating sufficient financial resources to spur economic development has remained a key constraint in the case of Pakistan. Thus, various streams of financing under the CPEC offer the country an opportunity to bridge the gap and boost economic growth and sustainable development. Pakistan is perhaps the only country where 
numerous Chinese-financed projects, as a key part of the grand "Belt and Road Initiative (BRI)," are under implementation.

The paper first introduces the background of the universal adoption of the UN 2030 Agenda and its SDGs at the global level and how substantial external financing is needed to enable developing countries including Pakistan to implement the Agenda and accomplish the SDGs. In the second section, it describes the CPEC and its main goals and objectives, and then provides a detailed overview of various components of the CPEC in different sectors such as energy, infrastructure, special economic/industrial zones, and the Gwadar port projects. The third section elaborates on how investments in all these sectors would significantly advance the UN 2030 Agenda in Pakistan and enable the country to make tangible progress on a number of SDGs. While the CPEC is likely to have a direct positive impact on SDG7, SDG8, and SDG9, various other SDGs are also expected to get a boost once all CPEC projects are fully executed. The paper concludes that the CPEC as a key part of the BRI has the potential to connect and transform the whole South Asian subcontinent - if political disputes are resolved and an atmosphere of mistrust and paranoia is replaced by an environment of trust, solidarity, and a joint endeavor against extreme poverty.

\section{Adoption of the UN 2030 Agenda: Implications for Developing Countries}

Before the deadline of meeting the Millennium Development Goals (MDGs) in the year 2015, the international community was deliberating on a new and a much diverse global development agenda. To this end, one of the preliminary steps was policy formulation of the UN Conference on Sustainable Development held in Brazil in 2012. On that occasion, UN member states vowed to continue the unfinished agenda of the MDGs and frame a comprehensive set of SDGs. It was pointed out that "poverty eradication is the greatest global challenge facing the world today and an indispensable requirement for sustainable development." ${ }^{1}$

To come up with a comprehensive and multidimensional development agenda, participants decided to create an Open Working Group (OWG) of

${ }^{1}$ UNGA, The Future We Want (New York: United Nations, 2012), p. 1. 
30 members to ensure "fair, equitable and balanced geographical representation." ${ }^{2}$ In addition, the United Nations Development Group (UNDG) selected 11 major themes for global consultations concerning the post-2015 development agenda. These subjects centered on various dimensions of development issues consisting of conflict and fragility, education, energy, environmental sustainability, food security, governance, growth and employment, health, inequalities, population dynamics, and water. ${ }^{3}$ To get a representative picture of the key global issues, 88 national consultations were held in many countries, engaging more than one million people from diverse backgrounds and age groups. In light of this, a report entitled $A$ Million Voices: The World We Want was released by the UN in 2013. The findings revealed that participants across different countries prioritized a number of key challenges: ending extreme poverty and hunger, accomplishing gender equality, improving health services and access to education for every child, employment and decent work, better transport and roads, reliable energy at home, access to clean water and sanitation, as well as protection of forests, rivers, and oceans. ${ }^{4}$ This report provided insights for the formulation of the post-2015 development agenda and the subsequent SDGs.

During the Third International Conference on Financing for Development held in Addis Ababa in July 2015, all UN member states agreed to strengthen the framework to finance sustainable development. It was stated that this could be done by means of intensifying efforts to increase resource mobilization, both domestic and external, for effectively implementing the post-2015 development agenda. With the Addis Ababa Action Agenda (AAAA), all stakeholders committed to boost financing for development and "to ensure that the actions to which we commit are implemented and reviewed in an appropriate, inclusive, timely and transparent manner." ${ }^{15}$

Two months later, during its 70th session in September 2015, the UNGA embraced the post-2015 development agenda as Transforming Our

${ }^{2}$ Ibid., p. 47.

${ }^{3}$ UNDG, A Million Voices: The World We Want (New York: United Nations Development Group, 2013).

${ }^{4}$ Ibid.

${ }^{5} \mathrm{UN}$, Addis Ababa Action Agenda of the Third International Conference on Financing for Development (New York: United Nations, 2015). 
World: The 2030 Agenda for Sustainable Development. ${ }^{6}$ The essential components of the UN 2030 Agenda are the 17 SDGs and 169 targets centered on five principles of people, planet, prosperity, peace, and partnership. The international community pledged to eliminate worldwide poverty, to combat inequalities, "to build peaceful, just and inclusive societies; to protect human rights and promote gender equality and the empowerment of women and girls; and to ensure the lasting protection of the planet and its natural resources." ${ }^{7}$ The declaration restates continuation of the incomplete agenda of the MDGs and striving to achieve, until 2030, what remains unfulfilled regarding these globally avowed development goals and targets.

\section{Developing countries} need multiple sources of funding to implement the UN 2030 Agenda.
It goes beyond doubt that implementing the UN 2030 agenda and attaining the SDGs require unprecedented determination at numerous levels: local, national, regional and transnational. Hence, SDG17 asks for a renewed global partnership, stating that the international community is "determined to mobilize the means required to implement this Agenda through a revitalized Global Partnership for Sustainable Development...with the participation of all countries, all stakeholders and all people." ${ }^{8}$ Similarly, the Addis Ababa Action Agenda has asserted that "achieving an ambitious post-2015 development agenda, including all the Sustainable Development Goals, will require an equally ambitious, comprehensive, holistic and transformative approach with respect to the means of implementation." 9

It is estimated that an aggregate of US\$3.3-4.5 trillion are required annually to implement the UN 2030 Agenda and achieve the SDGs

${ }^{6}$ UNGA, Transforming Our World: The 2030 Agenda for Sustainable Development (New York: United Nations, 2015).

${ }^{7}$ Ibid., p. 3.

${ }^{8}$ Ibid., p. 2.

${ }^{9} \mathrm{UN}$, Addis Ababa Action Agenda of the Third International Conference on Financing for Development, p. 4. 
globally. ${ }^{10}$ A World Bank document states that alongside the over US\$130 billion in the form of foreign aid, there are many other kinds of financing contributing to sustainable development, including philanthropy, remittances, South-South Cooperation and foreign direct investment (FDI) "together these sources amount to nearly US\$1 trillion." ${ }^{11}$ Nevertheless, excluding the above-mentioned available resources of one trillion, "the annual SDG financing gap in developing countries is estimated at approximately US $\$ 2.5$ trillion." ${ }^{\prime 2}$ To generate and mobilize resources at such scale, SDG17 has asked to

mobilize additional financial resources for developing countries from multiple sources... enhance North-South, South-South and triangular regional and international cooperation on and access to science, technology and innovation and enhance knowledge sharing. ${ }^{13}$

Similarly, it has been emphasized that a holistic approach comprising "financial support, capacity building, knowledge sharing and technology transfer" will play a critical role, keeping in view the context and needs of a particular country and region. ${ }^{14}$ Also, FDI has been identified in the Addis Ababa Action Agenda as a vital complement to national development efforts. There is a broad consensus that "investments in developing countries - and even in the least developed countries - are seen as business opportunities...companies provide jobs, infrastructure, innovation and social services." 15

${ }^{10}$ World Bank, From Billions to Trillions: Transforming Development Finance Post-2015 (Washington, DC: World Bank Group, 2015).

${ }^{11}$ Ibid., p. 1.

${ }^{12}$ OECD, Development Co-Operation Report 2016: The Sustainable Development Goals as Business Opportunities (Paris: Organization for Economic Cooperation and Development, 2016), p. 69.

${ }^{13}$ UNGA, Transforming Our World: The 2030 Agenda for Sustainable Development, p. 26.

${ }^{14}$ United Nations, Trends and Progress in International Development Cooperation (New York: Department of Economic and Social Affairs, United Nations, 2014), p. 6.

${ }^{15}$ OECD, Development Co-Operation Report 2016: The Sustainable Development Goals as Business Opportunities, p. 17. 


\section{The CPEC: Goals and Significance}

It is clear that the UN 2030 Agenda and its SDGs are quite comprehensive in nature and scope, and that its implementation in Pakistan requires substantial financial as well as non-financial resources. During much of the 15year period of the Millennium Development Goals (MDGs) framework, Pakistan was unfortunately faced with numerous challenges that compounded the country's problems and made implementation of the MDGs impossible. Among these, the biggest challenge was terrorism and the deteriorating law and order situation, which essentially left Pakistan in a state of war. In terms of financial damages, the war has cost Pakistan over US $\$ 126$ billion as it has affected the country's exports, led to reduction in the inflows of foreign investment, caused massive additional security spending on numerous military operations, affected the tourism industry, damaged physical infrastructure and resulted in displacement of thousands of people from conflict affected areas. ${ }^{16}$ During this period, Pakistan was also severely affected by natural disasters. The 2005 Kashmir earthquake claimed the lives of 73,000 people while its financial cost was "estimated at approximately US\$5.2 billion." ${ }^{17}$ The 2010 floods also inflicted a "damage of US $\$ 10$ billion on country's economic structure." ${ }^{18}$ Due to all these events, the main focus of the Pakistani government has been on relief and recovery, which has hugely hampered the country's progress on the MDGs. ${ }^{19}$

In recent years, the law and order situation has significantly improved after the Pakistani military successfully carried out a number of operations against terrorists. For the first time in the history of Pakistan, two democratically elected governments completed their tenures. The first one handed over power to another elected government after the 2013 general elections and the latter completed its five-year term in May 2018. After

${ }^{16}$ Government of Pakistan, Pakistan Economic Survey 2017-2018 (Islamabad: Ministry of Finance, 2018).

${ }^{17}$ Asian Development Bank and World Bank, Pakistan 2005 Earthquake: Preliminary Damage and Needs Assessment (Islamabad: Asian Development Bank and World Bank, 2005).

${ }^{18}$ Government of Pakistan, Pakistan Economic Survey 2010-2011 (Islamabad: Ministry of Finance, 2011).

${ }^{19}$ LEAD Pakistan, Accelerating SDGs' Implementation: Lessons from Pakistan 2016-2017 (Islamabad: Leadership for Environment and Development, Pakistan, 2017). 
coming into power in 2013, the new government came up with a long-term development plan, Vision 2025, which aims to achieve the SDGs of increased energy flows and ensure food security and water availability particularly for the agricultural sector. ${ }^{20}$ The policy document has also identified education, health, gender equality and environment sustainability as primary goals to be achieved during the planned period. With its resource input, the CPEC offers an opportunity for Pakistan to move forward its Vision 2025 and achieve the UN 2030 Agenda, as well as some of the SDGs in the Pakistani context.

After assuming power, former Prime Minister Nawaz Sharif visited China in July 2013. During his visit, the two countries signed a Memorandum of Understanding (MoU) in Beijing in the presence of Chinese Premier Li Keqiang. Aimed at enhancing investment in

The CPEC aims to generate win-win benefits for both Pakistan and China. energy, trade and communication sectors, the MoU was designed to create linkages between the Western Region of China and Pakistan by establishing communication links and developing economic and trade corridors. Later on, the most significant development took place during President Xi Jinping's visit to Islamabad during April 20-21, 2015. The two countries signed 51 MoUs related to the CPEC and displayed diverse aspects of close ties. ${ }^{21}$ President Xi's visit, with all the subsequent agreements, joint statements and the announcement of US $\$ 46$ billion investments in the form of the CPEC, set the tenor for future Pakistan-China relations. A well-known expert on ChinaPakistan relations sums up the significance of the CPEC for both countries:

A number of the objectives of the multifaceted One Belt, One Road scheme converge in Pakistan, including the outsourcing of industrial capacity, the search for growth drivers in the Chinese interior, the push to build up new markets for Chinese exports, efforts to stabilize China's western periphery and

${ }^{20}$ Government of Pakistan, Pakistan 2025: One Nation One Vision (Islamabad: Ministry of Planning, Development and Reform, 2014).

${ }^{21}$ Mateen Haider and Irfan Haider, "Economic Corridor in Focus as Pakistan, China Sign 51 MOUs," Dawn.com, April 20, 2015, http://www.dawn.com/news/1177109. 
comprehensively address the threat of rising militancy, and plans for alternative transportation routes that diversify the usual maritime conduits. ${ }^{22}$

In view of this, he states that "the CPEC has become the flagship project of Xi's flagship initiative." 23 The key vision and mission of the CPEC is "to improve the lives of people of Pakistan and China by building an economic corridor promoting bilateral connectivity, construction, explore potential bilateral investment, economic and trade, logistics and people to people contact for regional connectivity." ${ }^{24}$ Therefore, the main objectives and potential significance of the CPEC are

...regional connectivity, improving transport infrastructure, energy supply, trade and commerce, peace and development, diverse investment opportunities, industrial, financial and agricultural cooperation, tourism, educational linkage, human resource development, enhanced health opportunities, increase in livelihood opportunities and enhanced security and stability of the region. ${ }^{25}$

In the much-awaited policy document, released by both governments in November 2017 entitled Long Term Plan (LTP) for China-Pakistan Economic Corridor (2017-2030), seven salient features including connectivity, energy, trade and industrial parks, agricultural development and poverty alleviation, tourism, cooperation in areas concerning people's livelihood, and nongovernmental exchanges and financial cooperation have been identified. ${ }^{26}$ This document also asserts that "the CPEC will greatly speed up the

${ }^{22}$ Andrew Small, Beyond India-Centricity - China and Pakistan Look West (Seattle, Washington: National Bureau of Asian Research, 2016), p. 169.

${ }^{23}$ Ibid., p. 170.

${ }^{24}$ CPEC Secretariat, "CPEC Vision \& Mission," http://cpec.gov.pk/vision-mission/3.

25 “CPEC Significance/Potential," http://cpec.gov.pk/significance-potential/4.

${ }^{26}$ Government of Pakistan: Ministry of PDR and People's Republic of China: National Development \& Reform Commission, Long Term Plan for China-Pakistan Economic Corridor (2017-2030) (Islamabad: Government of Pakistan: Ministry of Planning, Development and Reform \& People's Republic of China: National Development \& Reform Commission, 2017). 
industrialization and urbanization process in Pakistan and help it grow into a highly inclusive, globally competitive and prosperous country capable of providing high-quality life to its citizens." 27 This relates to the SDGs either directly or indirectly and complement the internationally recognized development goals in many ways. Hence, successful implementation of the CPEC is expected to play a substantive role in achieving several SDGs in Pakistan.

Indeed, during recent years, no other policy initiative has received more attention in Pakistan than the CPEC. The prime minister, federal and provincial ministers, as well as government officials have all expressed admiration and expectations. The US $\$ 46$ billion package of projects contained in the CPEC offers an exceptional opportunity to Pakistan to tackle some of the main barriers hindering its economic development, such as energy bottlenecks, poor connectivity, and limited attraction for foreign investors. The government estimates that investment in the form of the CPEC, which is about Rs800 billion annually or 2.8 percent of the current gross domestic product (GDP), "will spur economic activity and create around 2 million direct and indirect new jobs. ${ }^{28}$ Regional connectivity is also a key element elaborated on by the government in its long-term plan Pakistan Vision $2025 .{ }^{29}$ The policy document specifically mentions the CPEC as an integral element in realizing the potential of regional connectivity and trade with member states of the South Asian Association for Regional Cooperation (SAARC), the Association of South East Asian Nations (ASEAN), the Central Asia Regional Economic Cooperation (CAREC), and the Economic Cooperation Organization (ECO). It is believed that "the China-Pakistan Economic Corridor (CPEC) offers a unique opportunity to Pakistan to integrate with regional developments and become a hub for trade and manufacturing with Gwadar port developed as an international free port." 30

The CPEC is equally beneficial for China as it offers a win-win situation for both countries once its various components are properly executed.

${ }^{27}$ Ibid., p. 6.

${ }^{28}$ Government of Pakistan, Annual Plan 2016-2017 (Islamabad: Ministry of Planning, Development and Reform, 2016), p. 51.

${ }^{29}$ Government of Pakistan, Pakistan 2025: One Nation One Vision.

${ }^{30}$ Ibid., p. 89. 
According to the LTP, China envisions, via the CPEC, to further "promote economic and social development in Western China, accelerate the Belt and Road construction, leverage on China's advantages in capital, technology, production capacity and engineering operation" and spur the creation of a new open economic system. ${ }^{31}$ Thus, to various Chinese provinces including the less developed Xinjiang Uighur Autonomous Region, the CPEC offers a viable alternate land and sea route via Pakistan's Gwadar port. Once the CPEC becomes functional, foreign trade of west China through Pakistan via the Gwadar port will significantly reduce both cost and time for transportation. In this sense, the CPEC is "providing economic support to a longtime ally and strategic hedge, facilitating trade, and building linkages to the west by which China can expand its influence." ${ }^{32}$ Clearly, both countries place high expectations on the CPEC.

\section{Key Components of the CPEC}

The overall implementation timeframe of the CPEC projects stretches to 2030. According to the LTP, all projects have been divided into three phases: the "short-term projects included will be considered up to 2020; mediumterm projects up to 2025; and long-term projects up to 2030."33 On the Pakistani side, CPEC projects are primarily managed by the Ministry of Planning, Development and Reform; on China's side, the National Development and Reform Commission (NDRC) is the key government body coordinating with its Pakistani counterpart. On July 20, 2013, the two sides established a high-level Joint Cooperation Committee (JCC) with working groups to focus on four key areas, namely, the Gwadar Port, transport infrastructure, energy, as well as trade and industrial cooperation. The JCC is responsible for the overall oversight and monitoring of the various

${ }^{31}$ Government of Pakistan: Ministry of PDR and People's Republic of China: National Development \& Reform Commission, Long Term Plan for China-Pakistan Economic Corridor (2017-2030), p. 9.

${ }^{32}$ Louis Ritzinger, The China-Pakistan Economic Corridor: Regional Dynamics and China's Geopolitical Ambitions (Seattle, Washington: National Bureau of Asian Research, 2015), p. 2.

${ }^{33}$ Government of Pakistan: Ministry of PDR and People's Republic of China: National Development \& Reform Commission, Long Term Plan for China-Pakistan Economic Corridor (2017-2030), p. 2. 
components of the CPEC and its proper implementation. On August 27, 2013, the CPEC Secretariat was inaugurated in Islamabad within the Ministry of Planning, Development and Reform. ${ }^{34}$ Ahsan Iqbal, Pakistan's Federal Minister for Planning, Development and Reform, and the visiting Chinese Vice Chairman of NDRC, Zhang Xiaoqiang, inaugurated the new unit exclusively dedicated to CPEC projects. Basically, the CPEC has four main components, comprising investment in the energy sector, building and upgrading communication infrastructure, developing special economic/industrial zones, and Gwadar port projects.

For the last several years, Pakistan has been suffering from acute energy shortfall. The situation has been aggravated since 2006 mainly on account of "inadequate capacity addition, limited exploration and ineffective exploitation of hydro, coal and renewable potential and inefficient use of energy resources." ${ }^{35}$ Consequently, the government has no alternative option but to reduce the supply of electricity and gas in the country. During times of acute need, particularly in summer, the overall shortfall in energy reaches 7,000 megawatts and it "intensifies the woes of consumers, disrupts industrial and agricultural production and adds to costs, making Pakistani products uncompetitive internationally." 36 As a government document indicates, the deficit has resulted in a detrimental effect on the economy, causing an estimated 4 to 7 percent loss to the country's GDP. It also has adverse effects on the society at large. Violent protests are held across the country, particularly in summer when the temperature rises above 40 degrees Celsius and electricity is unavailable from 8 to 12 hours a day, if not more.

Thus, the energy sector is not only one of the foremost recipients of Federal Public Sector Development Program (PSDP), but it is also a major component of the CPEC. As a result, "74 percent of the total China-Pakistan Economic Energy projects in Pakistan attract the most Chinese investment under the CPEC. Corridor (CPEC) projects are energy projects,

34 “Sino-Pak Corridor to Bolster Regional Development," Dawn.com, August 28, 2013, http://www.dawn.com/news/1038901/sino-pak-corridor-to-bolster-regional-development.

${ }^{35}$ Government of Pakistan, Annual Plan 2016-2017, p. xiii.

${ }^{36}$ Government of Pakistan, Pakistan 2025: One Nation One Vision, p. 16. 
which include coal, hydro and wind. ${ }^{\prime \prime 37}$ In fact, out of the total US $\$ 46$ billion investments under the CPEC, over US $\$ 34$ billion have been allocated for the energy component. The Pakistani government has stated in its Vision 2025 policy document that it aims to "eliminate [the] current electricity supply-demand gap by 2018, and cater to growing future demand by addition of 25,000 MW by 2025." ${ }^{38}$ The same document claims that early harvest or short-term projects in the CPEC will add 10,400 MW energy to the national grid by 2018 . If this is achieved, it would significantly reduce the chronic energy shortfall and enable relief from prolonged load-shedding. A detailed list of all energy projects to be completed under the CPEC is given in Tables 1 and 2, which indicate the total number of projects in the energy sector as well as the capacity and estimated cost of each project. It must be noted that some of these projects include renewal and upgrade of transmission lines.

Table 1. Prioritized Energy Projects Under the CPEC.

\begin{tabular}{|c|c|c|c|}
\hline & Project Name & MW & $\begin{array}{l}\text { Estimated } \\
\text { Cost (US\$M) }\end{array}$ \\
\hline 1 & $\begin{array}{l}2 \times 660 \mathrm{MW} \text { Coal-Fired Power Plants at Port Qasim } \\
\text { Karachi, Sindh }\end{array}$ & 1,320 & 1,980 \\
\hline 2 & Suki Kinari Hydro power Station, KPK & 870 & 1,802 \\
\hline 3 & Sahiwal $2 \times 660 \mathrm{MW}$ Coal-fired Power Plant, Punjab & 1,320 & 1,600 \\
\hline 4 & $\begin{array}{l}\text { Engro Thar Block II } 2 \times 330 \text { MW Coal fired Power Plant } \\
\text { TEL } 1 \times 330 \text { MW Mine Mouth Lignite Fired Power Project at Thar } \\
\text { Block-II, Sindh, Pakistan } \\
\text { ThalNova } 1 \times 330 \text { MW Mine Mouth Lignite Fired Power Project at } \\
\text { Thar Block-II, Sindh, Pakistan } \\
\text { Surface mine in block II of Thar Coal field, } 3.8 \text { million tons/year }\end{array}$ & $\begin{array}{l}660 \\
330 \\
330\end{array}$ & $2,000+1,470$ \\
\hline 5 & Hydro China Dawood 50 MW Wind Farm(Gharo, Thatta) & 50 & 125 \\
\hline 6 & Gwadar Coal/LNG/Oil Power Project, Gwadar & 300 & 600 \\
\hline 7 & HUBCO coal power plant $1 \times 660 \mathrm{MW}$, Hub Balochistan & 660 & 970 \\
\hline 8 & $\begin{array}{l}300 \text { MW Imported Coal Based Power Project at Gwadar, } \\
\text { Pakistan }\end{array}$ & 300 & 600 \\
\hline 9 & Quaid-e-Azam 1000 MW Solar Park, Bahawalpur, Punjab & 1,000 & 1,302 \\
\hline 10 & UEP $100 \mathrm{MW}$ wind Farm, Jhimpir, Sindh & 100 & 250 \\
\hline 11 & Sachal 50 MW Wind Farm, Jhimpir, Sindh & 50 & 134 \\
\hline
\end{tabular}

${ }^{37}$ Government of Pakistan, Pakistan Economic Survey 2015-2016 (Islamabad: Ministry of Finance, 2016), p. xiii.

${ }^{38}$ Government of Pakistan, Pakistan 2025: One Nation One Vision, p. 59. 
Table 1. (Continued)

\begin{tabular}{|c|c|c|c|}
\hline & Project Name & MW & $\begin{array}{c}\text { Estimated } \\
\text { Cost (US\$M) }\end{array}$ \\
\hline 12 & $\begin{array}{l}\text { SSRL Thar Coal Block-I, } 6.8 \text { mtpa \&SEC Mine Mouth } \\
\text { Power Plant }(2 \times 660 \mathrm{MW})\end{array}$ & 1,320 & $2,000+1,300$ \\
\hline 13 & Karot Hydropower Station, AJK \& Punjab & 720 & 1,420 \\
\hline 14 & $\begin{array}{l}\text { Three Gorges Second Wind Power Project } \\
\text { Three Gorges Third Wind Power Project }\end{array}$ & $\begin{array}{l}50 \\
50\end{array}$ & 150 \\
\hline 15 & $\begin{array}{l}\text { CPHGC 1,320 MW Coal-fired Power Plant, Hub, } \\
\text { Balochistan }\end{array}$ & 1,320 & 1,940 \\
\hline 16 & Matiari to Lahore Transmission line & & 1,500 \\
\hline & $\begin{array}{l}\text { Matiari (Port Qasim) — Faisalabad Transmission Line } \\
\text { Project }\end{array}$ & & 1,500 \\
\hline 17 & $\begin{array}{l}\text { Thar Mine Mouth Oracle Power Plant (1320 MW) \& sur- } \\
\text { face mine (Thar Block IV) }\end{array}$ & 1,320 & 1,300 \\
\hline & Total & 11,110 & 23,943 \\
\hline
\end{tabular}

Source: CPEC Secretariat. ${ }^{39}$

Table 2. Actively Promoted Energy Projects Under the CPEC.

\begin{tabular}{llcc}
\hline \multicolumn{1}{c}{ Project Name } & $\begin{array}{c}\text { Expected } \\
\text { Capacity } \\
\text { in MW }\end{array}$ & $\begin{array}{c}\text { Estimated } \\
\text { Cost } \\
\text { (US\$M) }\end{array}$ \\
\hline 1 & Kohala Hydel Project, AJK & 1,100 & 2,397 \\
2 & Rahimyar Khan Imported Fuel Power Plant 1320 MW & 1,320 & 1,600 \\
3 & Cacho 50 MW Wind Power Project & 50 & N/A \\
4 & Western Energy (Pvt.) Ltd. 50 MW Wind Power Project & 50 & N/A \\
& Total & 2,520 & 3,997 \\
\hline
\end{tabular}

Source: CPEC Secretariat. ${ }^{40}$

Like CPEC projects in other sectors, the Pakistani government is very optimistic about projects in the energy sector and has stated that CPEC "energy projects will serve as a backbone of the energy strategy to overcome power crisis in Pakistan." 41 Another important feature of the CPEC energy projects, as envisioned by the government, is "to improve the

${ }^{39} \mathrm{CPEC}$ Secretariat, “Energy Projects Sino-Pak Corridor to Bolster Regional Development," http://cpec.gov.pk/energy.

${ }^{40}$ Ibid.

${ }^{41}$ Ibid., p. 61. 
energy mix with a larger share of coal, hydel and renewable energy sources." ${ }^{22}$ As shown in Tables 1 and 2, although there is a mix of coal, hydro and wind power projects, the majority of them will make use of coal. The country has "an enormous amount of untapped coal reserves (around 186 billion tons)" and that is why it aims to increase domestic coal production from 4.5 to 60 million tons annually. ${ }^{43}$ Regarding environmental concerns of $\mathrm{CO}_{2}$ emissions associated with coal-based thermal power projects, the government has committed to adopt clean coal combustion technologies along with strong policies to make its use eco-friendly and conform to international standards. ${ }^{44}$

The CPEC infrastructure includes upgrade and improvement of existing communication facilities as well as establishment of new ones. An aggregate of US $\$ 11$ billion or about 26 percent of the total planned investment has been allocated for numerous infrastructure projects in Gwadar and in other areas along the CPEC route. It is important to mention that a number of other projects in the transport and communication sector have been funded by the Pakistani government under its Public Sector Development Program (PSDP). Thus, only those

\section{CPEC infrastructure} projects will greatly enhance connectivity in Pakistan and South Asia. projects funded by China under the CPEC are listed in Tables 1 and 2.

In its Vision 2025 plan, the Pakistani government has listed "modernizing transport infrastructure and regional connectivity" among the seven key elements. ${ }^{45}$ The policy document also mentions that transport

\footnotetext{
${ }^{42}$ Ibid., p. 70.
}

${ }^{43}$ Ibid., p. 61.

${ }^{44}$ Although both the Pakistani and Chinese governments assert that they have been using latest technology to minimize the negative implications of coal-based power generation plants, there are voices in Pakistan that warn about the repercussions of coal as a primary and long-term source of energy. See for example, Muhammad Hamid Zaman, “Environment: Not for Sale," The Express Tribune, December 27, 2016, https://tribune.com.pk/ story/1276746/environment-not-sale/; Farrukh Saleem, "Coal Power," The News International, March 26, 2017, http://www.pakdiscussion.com/coal-power-farrukh-saleem/; and Murad Ali, “Coal-Based Energy," Ibid., February 9, 2017, https://www.thenews.com.pk/print/184919Coal-based-energy.

${ }^{45}$ Government of Pakistan, Pakistan 2025: One Nation One Vision, p. 10. 
contributes to 10 percent of the country's GDP and about 6 percent of the overall employment. However, roads account for 96 percent of freight and passenger transportation in the country and the role of railways is quite minimal. Lack of efficient transport and communication networks costs the country's economy 4 to 6 percent of GDP annually. Therefore, Vision 2025 aims to "ensure reduction in transportation costs, safety in mobility, effective connectivity between rural areas and markets/urban centers, interprovincial high-speed connectivity" and to establish high capacity transportation corridors connecting major regional trading partners. ${ }^{46}$ Along the CPEC route, there will be a total of " 11 major connection points, i.e., Kashgar, Gilgit, Islamabad, Lahore, Multan, Sukkur, Karachi, Peshawar, Quetta, D.I. Khan, and Gwadar based on regional transport characteristics as agreed by China and Pakistan." ${ }^{\prime 7}$

It is expected that increased connectivity will bring substantial dividends, in terms of reducing time of travel as well as financial costs. To this end, as shown in Table 3, the existing railway line from Peshawar to Karachi (ML-1) will be upgraded and expanded; the same line will also be improved and upgraded between Taxila and Havelian where a dry port is going to be built. According to the Government of Pakistan Annual Plan 2016-2017, after the completion of work on these tracks, trains will be able to travel at a speed of $160 \mathrm{~km}$ per hour in contrast to current limits of 60 to $105 \mathrm{~km}$ per hour, and it would "cut transit time from Karachi to Peshawar by half." ${ }^{48}$

Table 3. Infrastructure Projects Under the CPEC.

\begin{tabular}{|c|c|c|c|}
\hline & Project Name & $\begin{array}{l}\text { Length } \\
(\mathrm{KM})\end{array}$ & $\begin{array}{c}\text { Estimated } \\
\text { Cost (US\$M) }\end{array}$ \\
\hline \multicolumn{4}{|c|}{ Road Projects } \\
\hline 1 & KKH Phase II (Thakot-Havelian Section) & 120 & 1,366 \\
\hline & Peshawar-Karachi Motorway (Multan-Sukkur Section) & 392 & 2,980 \\
\hline 3 & Khuzdar-Basima Road N-30 (110 km) & 110 & 80 \\
\hline 4 & Upgrading of D.I.Khan (Yarik)-Zhob, N-50 Phase I (210 km) & 210 & 195 \\
\hline 5 & KKH Thakot-Raikot N35 remaining portion $(136 \mathrm{~km})$ & 136 & 719.8 \\
\hline
\end{tabular}

\footnotetext{
${ }^{46}$ Ibid., p. 86.

${ }^{47}$ Government of Pakistan, Annual Plan 2016-2017, p. 210.

${ }^{48}$ Ibid., p. 213.
} 
Table 3. (Continued)

\begin{tabular}{lcc}
\hline \multicolumn{1}{c}{ Project Name } & $\begin{array}{c}\text { Length } \\
(\mathrm{KM})\end{array}$ & $\begin{array}{c}\text { Estimated } \\
\text { Cost (US\$M) }\end{array}$ \\
\hline Rail Sector Projects & & \\
$3 \quad$ Expansion and reconstruction of existing Line ML-1 & 1,736 & 3,650 \\
$4 \quad$ Havelian Dry port (450 M. Twenty-Foot Equivalent Units) & & 65 \\
\hline Source: CPEC Secretariat. & &
\end{tabular}

Thus, projects aimed at developing and upgrading communication infrastructure under the CPEC are expected to bring significant benefits, including reduction in transportation costs and time of travel as well as enhancement in the safety of people and goods.

Another key component of the CPEC is the establishment of various industrial zones or Special Economic Zones (SEZs) along its different routes. As shown in Table 4, at the moment there are a total of nine prioritized SEZs that have been identified by the Pakistani and Chinese governments. It is believed that

...the dozens of dedicated industrial zones to be established along the routes of the CPEC will be an ideal platform where what China can provide will be meeting Pakistan's needs, and a golden opportunity to enable Pakistan to accelerate the aforementioned process of high-level industrialisation..$^{50}$

The Pakistani government also hopes that "the proposed Industrial Parks and SEZs along the China-Pakistan Economic Corridor (CPEC) route will bring investment from China therein, which will further improve the industrial output." ${ }^{51}$ Policy documents reveal that major potential locations will have such industrial and economic zones which will enable the country to "produce more internationally competitive products, both to improve its engineering image, and to tilt the trade balance more in its favour." ${ }^{25}$

${ }^{49}$ CPEC Secretariat, “CPEC Infrastructure Projects,” http://cpec.gov.pk/infrastructure.

${ }^{50}$ Liang Tong, "CPEC Industrial Zones and China-Pakistan Capacity Cooperation," Strategic Studies, Vol. 34/35, No. 4/1 (Winter 2014/Spring 2015), p. 176.

${ }^{51}$ Government of Pakistan, Annual Plan 2016-2017, p. 182.

${ }^{52}$ Tong, “CPEC Industrial Zones and China-Pakistan Capacity Cooperation,” p. 176. 
Table 4. Special Economic Zones Under the CPEC.

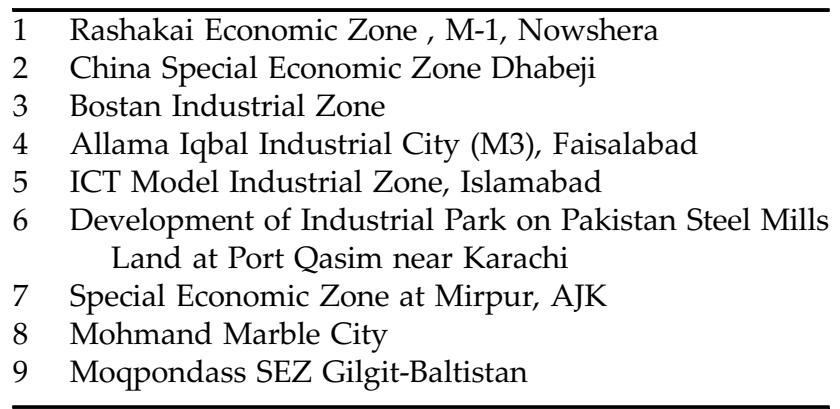

Source: CPEC Secretariat. ${ }^{53}$

As mentioned above, currently only nine locations have been identified, although media reports reveal that the Pakistani government had proposed 29 industrial parks and 21 mineral zones under the CPEC. ${ }^{54}$ A report by the Council on Foreign Relations (CFR), a U.S.based think tank, states that to fully utilize the newly established infrastructure and power capacity, Pakistan identified over 40 sites to build "industrial parks and special economic zones, designed to encourage investment and boost local employment." ${ }^{155}$ It has been stated that the focus will be on key industrial units comprising textiles and apparel, household appliances, motor vehicles, auto components and other transport equipment and vehicles, electrical machinery, light engineering industries, fabricated metal products, leather products, high and new technology including IT, pharmaceutical, and construction material industries, including marble, granite, cement, and other minerals. In view of this, the Pakistani government has set high expectations for the CPEC

${ }^{53}$ CPEC Secretariat, “CPEC Special Economic Zones," http://cpec.gov.pk/specialeconomic-zones-projects.

54"Govt Proposes 29 Industrial Parks, 21 Mineral Zones under CEPC," The News International, July 26, 2015, https://www.thenews.com.pk/print/13780-govt-proposes-29industrial-parks-21-mineral-zones-under-cpec.

${ }^{55}$ Daniel S. Markey and James West, "The Stakes in the China-Pakistan Economic Corridor," Council on Foreign Relations, May 12, 2016, https://www.cfr.org/expert-brief/ behind-chinas-gambit-pakistan. 
and hopes that it will lead to the creation of "around 2 million direct and indirect new jobs." ${ }^{\prime 56}$

\section{The Gwadar port is of enormous}

economic and

strategic significance to China.

Last but not the least, the Gwadar port is a significant component of the CPEC. Gwadar is a small town in the South of Baluchistan province. After the development of deep-sea Gwadar Port with Chinese assistance, this place has attained unprecedented significance and is among the most important elements of all CPEC projects. Both the maritime and the land silk roads envisioned under the BRI are expected to converge in the CPEC and the port of Gwadar. The port is thus strategically important for China, particularly for its western region. In 2013, Pakistan handed over the contract of running the port to a Chinese state-run company, China Overseas Ports Holding Company Limited. ${ }^{57}$ As Table 5 indicates, China has been financing various ventures relating to port development, communication, education, energy and medical facilities. According to the plans, the Gwadar port is to be linked with west China, Xinjiang in particular, by a modern road and rail system as well as by air with the construction of an international airport.

Table 5. Gwadar Projects Under the CPEC.

\begin{tabular}{llc}
\hline & \multicolumn{1}{c}{ Project Name } & Estimated Cost (US\$M) \\
\hline 1 & East-Bay Expressway & 140.60 \\
2 & Gwadar International Airport & 230.00 \\
3 & Construction of Breakwaters & 123.00 \\
4 & Dredging of berthing areas \& channels & 27.00 \\
5 & Infrastructure for Free Zone \& EPZs port related & 32.00 \\
& $\quad$ industries & 130.00 \\
6 & Necessary Facilities of Fresh Water Treatment and & 100.00 \\
& $\quad$ Supply \\
7 & Pak-China Friendship Hospital & \multirow{2}{*}{} \\
\hline
\end{tabular}

${ }^{56}$ Government of Pakistan, Annual Plan 2016-2017, p. 51.

57 “Gwadar Port Handed over to China," The Express Tribune, February 18, 2013, http:// tribune.com.pk/story/509028/gwadar-port-handed-over-to-china/. 
Table 5. (Continued)

\begin{tabular}{llc}
\hline \multicolumn{1}{c}{ Project Name } & Estimated Cost (US\$M) \\
\hline 8 & Technical and Vocational Institute at Gwadar & 10.00 \\
9 & Gwadar Smart Port City Master Plan \\
10 & $\begin{array}{c}\text { Bao Steel Park, petrochemicals, stainless steel and other } \\
\text { industries in Gwadar }\end{array}$ & NA \\
11 & $\begin{array}{c}\text { Development of Gwadar University (Social Sector } \\
\text { Development) }\end{array}$ & NA \\
12 & $\begin{array}{c}\text { Upgrading and development of fishing, boat making } \\
\text { and maintenance services to protect and promote } \\
\text { livelihoods of local population }\end{array}$ & NA \\
\hline Source: CPEC Secretariat. & 58
\end{tabular}

Once fully implemented, the Gwadar port will generate enormous benefits for both countries. In terms of reduction in distance, seven Chinese provinces, particularly the less developed Xinjiang Uighur Autonomous Region, will no longer have to import and export commodities through the ports of east China that are about 4,500 to 5,000 kilometers away. Notably, these provinces are now conducting trade with Asian, European, and African countries through sea-routes of over 10,000 kilometers. ${ }^{59}$ With the completion of the Gwadar port, international trade of west China could be conducted through Gwadar which is about 2,000 kilometers away from Kashgar, a key trading hub of Xinjiang that borders Afghanistan, Kyrgyzstan, Pakistan, and Tajikistan. Consequently, distance for shipments will be significantly reduced, which definitely translate to time and cost savings. Another significant factor for China is the geo-strategic location of the Gwadar port, since it provides an alternative short access to the Indian Ocean, which is free of the conflict that characterizes the South China Sea outlet. It can also reduce China's dependence on the Strait of Malacca. ${ }^{60}$ As China is conscious of the vulnerability of maritime routes via the Strait

${ }^{58}$ CPEC Secretariat, “CPEC Gwadar Projects,” http://cpec.gov.pk/gwader.

${ }^{59} \mathrm{Lu}$ Shulin, "China-Pakistan Economic Corridor: A Flagship and Exemplary Project of 'One Belt and One Road,"' Strategic Studies, Vol. 34/35, No. 4/1 (Winter 2014/Spring 2015), p. 168.

${ }^{60}$ Hasan Askari Rizvi, “The China-Pakistan Economic Corridor: Regional Cooperation and Socio-Economic Development," ibid, p. 5. 
of Malacca, this would provide China with an alternative option and greatly minimize its "Malacca dilemma."

A full list of projects to be executed in Gwadar is given in Table 5. These include the construction of the East-Bay Expressway, the Gwadar International Airport, the breakwaters at the port, necessary facilities for fresh water treatment and supply in Gwadar, and a medical facility as well as a vocational training institute, the design of berthing areas and channels at the port, and the infrastructure for Export Processing Zones (EPZs) and port-related industries.

\section{The CPEC's Contribution to the UN 2030 Agenda in Pakistan}

The main objectives envisioned under the CPEC and the internationally recognized SDGs planned under the UN 2030 Agenda have lots of commonalities, and the two sets of goals complement each other in various ways. The mission, vision, and key objectives of the CPEC are poverty alleviation, economic prosperity, enhanced regional connectivity, and increased trade and investment opportunities. In the same way, key goals of the UN 2030 Agenda are to end all forms of global poverty and food insecurity and enable everyone to have access to education, health, clean drinking water, and decent job opportunities. Increased trade and connectivity will directly and indirectly contribute to accomplishment of many of these goals and objectives.

The three main components of the CPEC - self-sufficiency in energy, expansion and upgrade of communication infrastructure, and the process of industrialization - will enable the country to make huge strides towards three SDGs, namely SDG7 (ensuring access to affordable, reliable, sustainable and modern energy for all), SDG8 (promoting sustained, inclusive and sustainable economic growth, full and productive employment and decent work for all), and SDG9 (building resilient infrastructure, promoting inclusive and sustainable industrialization and fostering innovation). 61

If successfully implemented, the CPEC is expected to resolve the chronic issue of energy shortfall and the Pakistani people will have access to reliable, sustainable and modern means of energy. As this paper has

${ }^{61}$ UNGA, Transforming Our World: The 2030 Agenda for Sustainable Development. 
highlighted, energy deficiency has been a huge hindrance in economic growth of Pakistan. With the establishment of numerous planned SEZs and the process of industrialization, people will have better job opportunities and means of earning their livelihoods. Besides the creation of significant employment opportunities for skilled and semi-skilled labor force, the establishment of SEZs is expected to attract more FDI in the country, leading to a chain of productive economic activities. With substantial investments in the communication infrastructure, people are expected to have access to better roads and transport facilities. To sum up, these three SDGs are most relevant to CPEC projects and the country could progress significantly, provided various projects and ventures planned under the CPEC are successfully implemented.

Apart from contributing to the three SDGs directly, the CPEC is likely to help in achieving various other SDGs indirectly. For example, SDG1 states to "end poverty in all its forms everywhere," ${ }^{62}$ while poverty alleviation is one of the key objectives of the CPEC. As discussed earlier, the CPEC is expected to

The CPEC will directly foster achievement of several SDGs in Pakistan. create about 2 million direct and indirect employment opportunities across the country. It means about 2 million families will have better means of livelihood and subsequently achieve food security (SDG2), access to better health services (SDG3), quality education (SDG4) and clean water and sanitation (SDG6). There is little doubt that a person with a decent job is likely to spend more on the health and education of his/her family. Hence, in one way or another, the successful completion of the CPEC is likely to contribute to the accomplishment of various SDGs in Pakistan.

Another salient example of the CPEC's potential role in the attainment of the SDGs is its indirect contribution to SDG15, which aims to "protect, restore and promote sustainable use of terrestrial ecosystems, sustainably manage forests, combat desertification, and halt and reverse land degradation and halt biodiversity loss." ${ }^{63}$ There is a more likely situation to accomplish SDG15 if people have access to clean and cheap

${ }^{62}$ Ibid., p. 14.

${ }^{63}$ Ibid. 
energy. Like many other developing countries, Pakistan has "almost 30\% of the population without electricity - contributing to depletion of vital forest land." ${ }^{64}$ Therefore, if people have access to other viable sources of energy, this will substantially reduce and reverse deforestation and desertification. Currently, the forest is the only available option of energy use for people living in rural areas, which results in huge deforestation as people mostly rely on wood from the forest for cooking and heating purposes. If people have a reasonable alternative source of energy, they will naturally reduce their dependence on the forest, particularly in rural and hilly areas.

In addition, the CPEC offers a unique opportunity for convergence, harmonization and division of labor to a host of bilateral and multilateral actors to effectively implement SDG17, which entails "a revitalized Global Partnership for Sustainable Development...with the participation of all countries, all stakeholders and all people." ${ }^{\prime 65}$ As the CPEC could help solve numerous development issues with which Pakistan is faced, particularly issues related to infrastructure, trade and commerce, energy shortage, unemployment, and overall economic growth and development, it has significant potential for other actors and investors to get involved in the development of Pakistan.

\section{Conclusion}

The UN 2030 Agenda and its 17 SDGs are quite ambitious and their accomplishment requires equally ambitious response from all stakeholders. In this light, the CPEC offers an opportunity for regional actors to move forward the Agenda and help in achieving various SDGs even in the broader South Asian continent which is faced with numerous development challenges. As envisioned by the Government of Pakistan in its long-term policy plan Vision 2025, Pakistan's location at the crossroads of Central Asia, South Asia, and West Asia makes it ideally suitable for regional connectivity and inter-regional trade, and the country can materialize its "dream

${ }^{64}$ Government of Pakistan, Pakistan 2025: One Nation One Vision, p. 59.

${ }^{65}$ UNGA, Transforming Our World: The 2030 Agenda for Sustainable Development, p. 2. 
of becoming a regional trading hub." ${ }^{\prime 66}$ Yet for that to happen, it is essential to engage other investors and regional countries as well.

In Pakistan, the CPEC has been hailed as a game-changer not only for the country but for the entire region. While South Asia is the second most populous region in the world, it is also a region with the highest number of people suffering from acute poverty. Meanwhile, as one of the world's most dynamic regions, it is economically disintegrated. While inter-regional trade is about 25 percent among the ASEAN countries, in South Asia "intraregional trade accounts for just 5 percent of total trade. ${ }^{\prime 67}$ Hence, the region and its constituent countries are faced with myriad development challenges. According to the 2015 MDGs Report, "the overwhelming majority of people living on less than $\$ 1.25$ a day reside in two regions - Southern Asia and sub-Saharan Africa." ${ }^{\prime 68}$ The report further adds that in terms of overall poverty, about 80 percent of the global poor live in these two regions. According to the World Bank, "about 399 million people - 40 percent of the world's poor - live on less than \$1.25 a day" in South Asia. ${ }^{69}$ In all, South Asia's score on the Human Development Index (HDI) is 0.607 and life expectancy at birth is 68.4 years - little better than Sub-Saharan Africa whose HDI score is 0.518 and life expectancy at birth is 58.5 years. $^{70}$

In order to overcome these challenges, there is a need for more integration, interconnectivity, inter-regional trade, and huge investment in social sectors and infrastructure to increase regional connectivity. The CPEC has the potential to increase regional connectivity and inter-regional trade. Unfortunately, the CPEC is often viewed by India as a geostrategic gambit that will give China more

India-China collaboration can further unleash the potential of the CPEC and promote SDGs in South Asia.

${ }^{66}$ Aarish U. Khan, "Pak-China Economic Corridor: The Hopes and Reality," Regional Studies Vol. 33, No. 1 (2015). p. 59.

${ }^{67}$ World Bank, Annual Report 2015 (Washington, DC: World Bank Group, 2015), p. 50.

${ }^{68}$ UN, The Millennium Development Goals Report 2015 (New York: United Nations, 2015), p. 15.

${ }^{69}$ World Bank, Annual Report 2015, p. 50.

${ }^{70}$ UNDP, Human Development Report 2015: Work for Human Development (New York: United Nations Development Programme, 2015). 
visible footprints in South Asia. ${ }^{71}$ Rather than a source of increased regional connectivity, trade, tourism, people-to-people exchange, and prosperity, the CPEC has led to the creation of an atmosphere of mistrust and cynicism. Despite serious Indian antagonism toward the CPEC, some analysts argue that the greater role of China in Pakistan could lead to increased stability in the region, and that the CPEC will bring benefits to India as well.

It is argued that after substantial investment in numerous projects in Pakistan, and "increase in the number of its citizens on Pakistani soil, China will have a greater stake in regional peace and stability and could play a positive role to help resolve a future crisis." ${ }^{172}$ While trade and financial linkages are still limited between China and South Asia, there is vast potential to expand it and "unlock gains from trade, knowledge spillovers, risk sharing and diversification" for the greater benefit of countries in the region. ${ }^{73}$ Similarly, to fully utilize the dividends of China's "project of the century," it is "imperative for India and China to work together to build a more peaceful and prosperous future" for the future generations of South Asia. ${ }^{74}$ In sum, there is great opportunity to develop economic prosperity and make progress on the SDGs, provided regional actors sit together, address each other's concerns, resolve their bilateral disputes and join hands in their struggle against poverty, backwardness, illiteracy, and disease.

${ }^{71}$ Markey and West, "The Stakes in the China-Pakistan Economic Corridor,"; Jia Chunyang, "New Trends of US Policy toward South Asia: Challenges to CPEC," IPRI Journal, Vol. 17, No. 1 (2017); and R. Passi, “OBOR: Where the Economics Stop and the Geopolitics Begin," paper presented at the International Workshop on China's “One Belt, One Road" Global Strategy: Implications, Prospects and Constraints, Aalborg University Denmark, January 19-20, 2017.

${ }^{72}$ Gurmeet Kanwal, “Pakistan's Gwadar Port: A New Naval Base in China's String of Pearls in the Indo-Pacific," in Nicholas Szechenyi ed., China's Maritime Silk Road: Strategic and Economic Implications for the Indo-Pacific Region (Washington, DC: Center for Strategic and International Studies 2018), p. 13.

${ }^{73}$ Vivek Arora, Hui Tong, and Cristina Constantinescu, "China and South Asia: The Economic Dimension," in Thomas Fingar, ed. The New Great Game: China and South and Central Asia in the Era of Reform (Stanford, California: Stanford University Press, 2016), p. 274.

${ }^{74} \mathrm{Hu}$ Shisheng, “India's Rise and China's Response," ibid., p. 85. 